\title{
A new species of Pachytrocha Kent, 1882 (Ciliophora, Peritrichia: Vaginicolidae)
}

\author{
ELENA G. BOSHKO ${ }^{1} \&$ LYUDMILA A. KONSTANTYNENKO ${ }^{2}$ \\ ${ }^{1}$ Schmalhausen Institute of Zoology, B. Khmelnitsky str., 15, 01601, Kiev, Ukraine. E-mail: boshko@izan.kiev.ua \\ ${ }^{2}$ Ivan Franko Zhytomir State University, V. Berdychivska str., 40, 10008, Zhytomir, Ukraine. E-mail:Ikonstantynenko1@ rambler.ru
}

\begin{abstract}
The peritrich ciliate Pachytrocha zhytomirensis $\mathbf{n}$. sp. is described from the sewage treatment system of Zhytomir (Ukraine). The new species is characterized by an elongate, subgeniculate lorica sheltering a single zooid with an annular ridge and a peristomial lip thickened noticeably near the entrance to the infundibulum. When contracting, the upper part of the cell bends toward the wall of the lorica and the inflated edge of the peristomial lip covers the body. The macronucleus is ribbon-like and oriented parallel to the longitudinal axis of the cell. Cothurnia asymmetrica Sommer, 1951 is recognized as a synonym of Pachytrocha cothurnoides Kent, 1882.
\end{abstract}

Key words: taxonomy, morphology, species composition, activated sludge

\section{Introduction}

The genus Pachytrocha Kent, 1882 was described by Kent (1882) for peritrichous ciliates from pond macrophytes. The type species is Pachytrocha cothurnoides Kent, 1882 by monotypy (Aescht 2001). Representatives of the genus have a tubular lorica with an external stalk like species of Cothurnia Ehrenberg, 1831 and Pyxicola Kent, 1882, but differ from the former by possession of an asymmetrical thickening of the cell body and from the latter by absence of a secreted operculum that plugs the aperture of the lorica upon contraction. Subsequently, P. cothurnoides was reported by Dunning et al. (1888), Dalla Torre (1891), Fadeev (1929) (Pachytrocha cothurnioides) and Naidu (1965), Pachytrocha sp. was found by Paviour-Smith (1956). Pachytrocha was not recognized as valid by Bütschli (1887-1889), who synonymized it with Cothurnia. By contrast, Trueba (1978) synonymized Pachytrocha with Pyxicola based on the assumption that Kent (1882) mistakenly described individuals of a species of Pyxicola that had lost the operculum secreted on the side of the peristome as representatives of Pachytrocha.

In the recent extensive monographs on Cilophora the generic name Pachytrocha was cited both as valid name (Lom \& Puytorac 1994; Lynn 2008) and as a junior synonym of Pyxicola (Jankowski 2007). Guhl and Guhl (1993) and Jankowski (2007) have interpreted records of Pachytrocha cothurnoides as young individuals of Pyxicola (especially Pyxicola pusilla (Wrześniowsky, 1866) in which the operculum was not yet developed. Jankowski (2007) also believed that Cothurnia asymmetrica Sommer, 1951 is the juvenile form of Pyxicola.

Abundant individuals of a hitherto unknown species of loricate peritrich were observed during investigations of peritrichous ciliates in the aeration tanks of the sewage treatment system in Zhytomir, Ukraine in 2007. These ciliates had the enlargement of the peristomial lip that distinguishes representatives of the genus Pachytrocha. This paper describes the new species of the genus as Pachytrocha zhytomirensis $\mathbf{n}$. sp. Based on our information, the genus Pachytrocha was restored and redescribed. 


\section{Material and methods}

Activated sludge was collected from the sewage treatment plant from Zhytomir, Ukraine from February to June, 2007 at temperatures of $10-25^{\circ} \mathrm{C}$, and concentrations of dissolved oxygen of $2.7-7.2 \mathrm{mg} / \mathrm{L}$, and $\mathrm{pH}$ values of 7.15-7.77. The ciliates were investigated alive under a dissecting microscope and fixed in $4 \%$ formalin. Permanent preparations were made by staining with Heidenhain's hematoxylin. Photomicrographs were made using a DC 1300 digital video camera.

\section{Results and discussion}

The ciliates we investigated from activated sludge were noticeable in that the contracted individual flexed its cell body toward the higher, convexly curved wall of the lorica. The peristomial lip is grossly and asymmetrically thickened on the side opposite this wall (Figs. 1, 2, 4), so that upon contraction the ciliate covers itself with this peristomial bulge (Figs. 3, 5, 8, 10), which is the hyperdeveloped edge of the peristomial lip. Closure of the lorica aperture with a structure in the area of the peristomial lip is a characteristic of both Pyxicola and Pachytrocha. However, in Pyxicola the ciliate blocks its lorica aperture with a secreted operculum that acts like a stopper in a bottle and is attached to the face of a protrusion that arises beneath the peristomial lip. This is facilitated by the fact that the aperture of the lorica is a narrow, cylindrical "neck" that is distinct from the rest of the lorica, which is rounded, ovoid, and distinctly inflated relative to the neck. By contrast, the sole representative of the genus Pachytrocha described so far, $P$. cothurnoides, lacks a secreted operculum and closes the aperture of the lorica with a swelling beneath the peristome (Kent 1882).

In the ciliates that we investigated, there was a large bulge in the peristomial lip near the opening to the infundibulum (invaginated passageway leading to the cytostome), and secreted operculum was absent. The characteristic closure apparatus meant that the ciliate belonged to the genus Pachytrocha, and a number of peculiarities indicated that these ciliates were a new species.

The distinctive morphology and mode of function of the peristomial lip in the new species and in $P$. cothurnoides are sufficient to redefine the genus Pachytrocha and establish its validity. Cothurnia asymmetrica, which was described from the algae Cladophora sp. and Enteromorpha intestinalis and characterized by an asymmetrically thickened peristomial lip similar to the one we observed in our species, must be assigned to the genus Pachytrocha in our opinion. Based on the reported dimensions and morphology of C. asymmetrica (Sommer 1951), we believe that it should be a junior synonym of $P$. cothurnoides.

Living individuals of $P$. cothurnoides were found repeatedly and investigated in detail by Kent (1882) and Sommer (1951). As is evident from Peshkoff's (1934) paper, individuals of Pyxicola carteri Kent, 1882 start to feed only when they have completed metamorphosis and have a developed operculum. In our investigations on Pyxicola from Ukrainian waterways, we also observed that the operculum was developed in all active, feeding organisms. Thus, we are certain that the type species of the genus Pachytrocha is not a young individual of Pyxicola.

A description of the new species and redescription of the genus Pachytrocha are given below.

\section{Pachytrocha zhytomirensis n. sp.}

(Fig. 1-11)

Deposition of types. Holotype slide with holotype organism (Heidenhain's hematoxylin) was deposited in the Schmalhausen Institute of Zoology (No. IP207). Paratype slides contain paratype organisms (Heidenhain's hematoxylin) were deposited in the same collection (No. IP208-IP210) and in the collections of the Natural History Museum, London, U.K. (No. 2009:6:12:1 - 2009:6:12:4). 

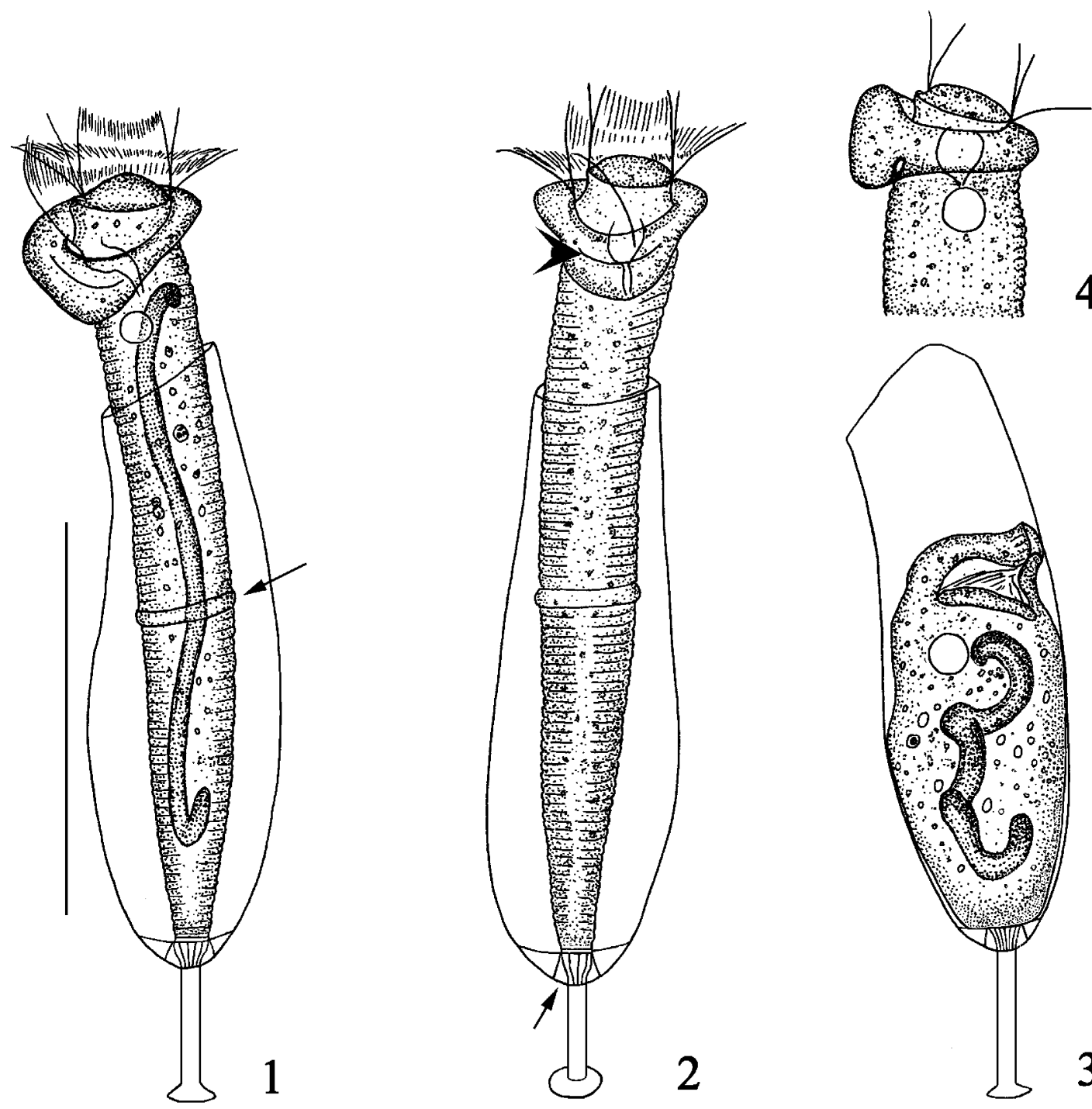

\section{4}

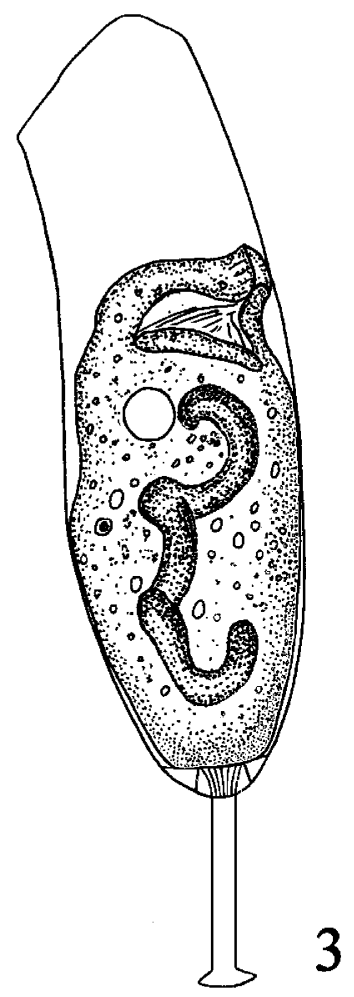

FIGURES 1-4. Living individuals of Pachytrocha zhytomirensis n. sp. 1, 2. Extended zooid (1-side view, arrow indicates annular ridge; 2 -frontal view, arrow indicates tubular passageway for stalk through base of lorica, arrowhead marks sulcus in the swollen peristomial lip). 3. Contracted zooid in side view. 4. Anterior end of zooid showing the thickened peristomial lip. Scale bars: $50 \mu \mathrm{m}$.

Etymology: The specific name is of Latin derivation and reflects the geographical distribution of this species in the city of Zhytomir.

Diagnosis: Lorica colorless, elongate, tubular, tapering gradually toward each end, widest in basal half. Base of lorica rounded. The lorica two-layered, but exfoliation of endotheca from exotheca (the latter are terms proposed by Jankowski 1989 for inner and outer layers of lorica) well-marked only in region of base of lorica near scopula and stalk. Distal part of lorica curved at angle of approximately $20^{\circ}$ with respect to longitudinal axis of body. Distal aperture moderately sloped, with even edges. Stalk consisting of three parts exostyle, mesostyle and endostyle (Jankowski's 1989 terms). External part of stalk (exostyle) relatively long and slender, provided with small basal disk at point of attachment to substrate. Mesostyle (stalk inside exotheca) wider than exostyle, longitudinally striated, and located in cone-shaped tubular passageway through base of lorica. Zooid attached to bottom of endotheca by low, wide disc (modified endostyle).

Lorica with single zooid. Cell body elongate, with prominent, annular ridge located slightly aboral to midpoint of body. Pellicle with distinct transverse striations. Peristomial disc large, prominent. Peristomial lip wide, extending well beyond maximal body width and unequal in thickness. Ventral side of peristomial lip 
near entrance to infundibulum extremely thick (twice as thick as dorsal side), with noticeable sulcus running transversely across it. When ciliate contracts, distal part of cell body bends toward concave side of lorica wall, and swollen edge of peristomial lip covers rest of cell body. Contractile vacuole located beneath peristomial lip near ventral wall of short infundibulum. Macronucleus elongate and ribbon-like with slightly recurved tips, oriented along longitudinal axis of body. Micronucleus located near aboral end of macronucleus. Adoral zone of cell body protruding as much as $37 \mu \mathrm{m}$ from lorica when expanded. The telotroch is symmetric, elongated and cylindrical, without lamellar ring as in Cyclodonta Matthes, 1958.
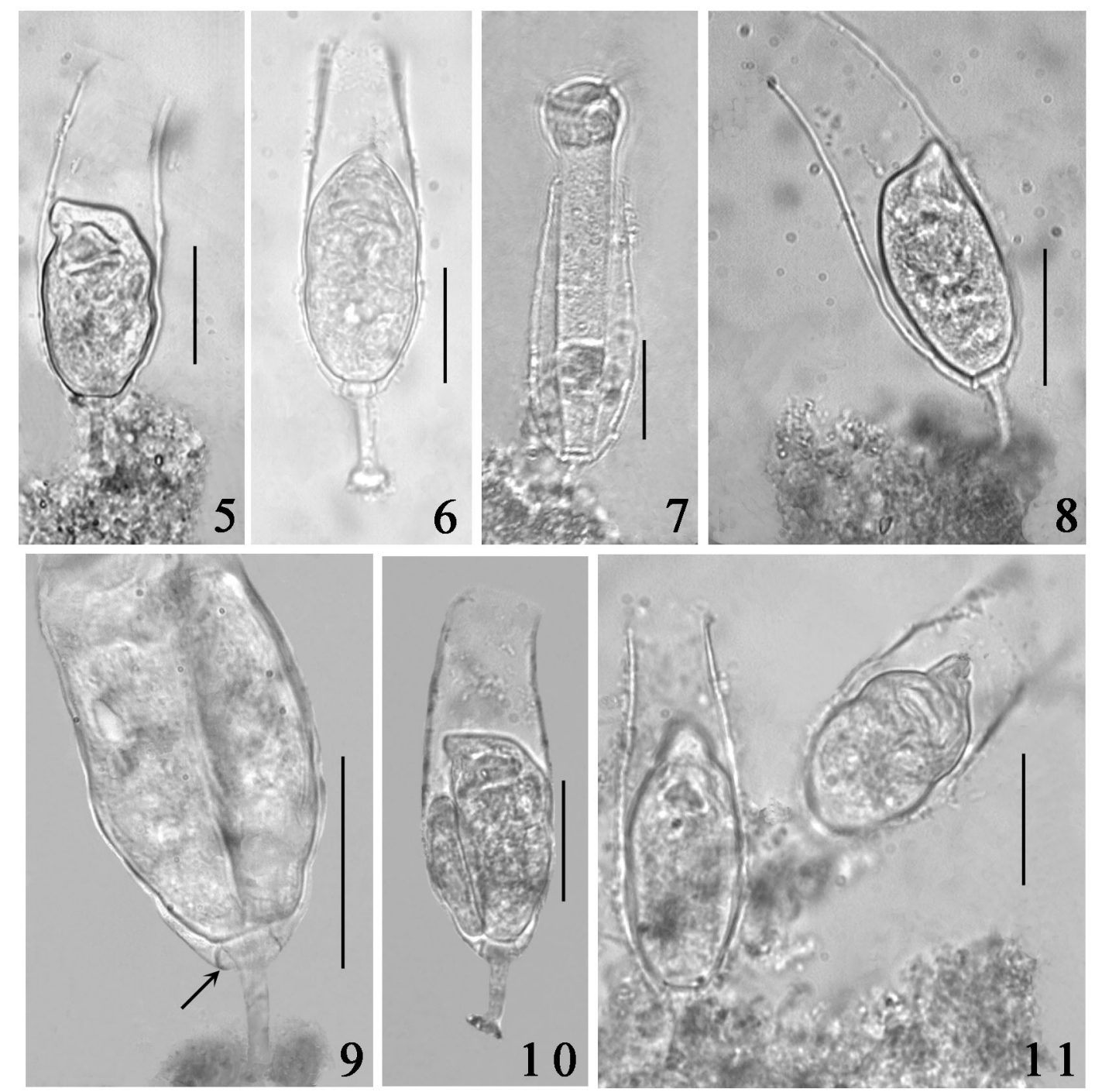

FIGURES 5-11. Photomicrographs of living Pachytrocha zhytomirensis n. sp. (7) and formalin-fixed zooids (5, 6, 811). 5, 8, 10 -side views. 6, 7, 11 -frontal views. 9. Basal part of lorica in side view showing stalk and passageway through base of lorica (arrow). The two individuals are a zooid (at left) and telotroch (at right) formed by asexual division. 10. Lorica with zooid and telotroch (at left). 11. Attachment of one individual to the lorica of another. Scale bars: $25 \mu \mathrm{m}$.

Dimensions of body $90.0-98.5 \times 10.0-17.0 \mu \mathrm{m}(94.8 \pm 2.3 \times 13.9 \pm 2.1 ; \mathrm{n}=18)$. Width of peristomial lip $17.5-23.7 \mu \mathrm{m}(21.0 \pm 2.1 ; \mathrm{n}=18)$. Dimensions of lorica $62.5-77.5 \times 20.0-27.5 \mu \mathrm{m}(71.8 \pm 3.3 \times 24.3 \pm$ $3.0 ; \mathrm{n}=30)$. Width of aperture $12.5-17.5 \mu \mathrm{m}(15.9 \pm 1.5 ; \mathrm{n}=30)$. External stalk up to $20.0 \mu \mathrm{m}$ long $(16.6$ $\pm 4.0 ; \mathrm{n}=30$ ). Width of exostyle approximately $2.5 \mu \mathrm{m}$. Dimensions of mesostyle approximately $3.5 \times 5.0 \mu \mathrm{m}$. Dimensions of telotroch fixed in formalin approximately $35.0 \times 21.0 \mu \mathrm{m}$. 
Differential diagnosis: The new species differs from Pachytrocha cothurnoides in shape of the lorica and by having an elongate zooid with a well-marked annular ridge. Pachytrocha cothurnoides has a less elongate lorica that is wider in relation to its width than in P. zhytomirensis n. sp. and its basal part is also more bulbous. Among all species from the closely-related genera Cothurnia and Pyxicola, the new species has several characters similar to Cothurnia angusta Kahl, 1933 (lorica shape, dimensions) and C. annulata Stokes, 1885 (partially lorica shape, cell body with annular ridge, the mesostyle located in tubular passageway). However, it differs from these species by having a peristomial lip that is unequal in thickness and when contracting, the upper part of the ciliate's cell body bends toward the wall of the lorica.

\section{Genus Pachytrocha Kent, 1882 emended}

Diagnosis: Solitary peritrichous ciliates with epistyliform peristome and tubular, thin-walled, rigid lorica attached to substrate by means of external stalk. Portion of peristomial lip near entrance of infundibulum much wider than rest of lip. Secreted operculum absent; when contracted, cell body protected by thickened portion of peristomial lip. Genus with two known species: $P$. cothurnoides Kent, 1882 (type species), and $P$. zhytomirensis $\mathbf{n} . \mathbf{s p}$.

\section{Acknowledgement}

We would like to thank Dr. Igor Dovgal (Schmalhausen Institute of Zoology, Kiev, Ukraine) for his helpful comments and help in translation of our paper into English. We very grateful to Prof. John Clamp (North Carolina Central University, Durham, North Carolina, USA) for his critical reading of the manuscript with useful comments and for improving the English. The suggestions of two other anonymous reviewers are also acknowledged.

\section{References}

Aescht, E. (2001) Catalogue of the generic names of ciliates (Protozoa, Ciliophora). Denisia, 1, 1-350.

Bütschli, O. (1887-1889) Protozoa. Abt. III. Infusoria und System der Radiolaria. In: H.G. Bronn (Ed.), Klassen und Ordnungen des Thier-Reichs, 1. C. F. Winter, Leipzig, pp. 1098-2035, Pl. 56-79.

Dalla Torre, K.W. von. (1891) Studien über die mikroskopische Thierwelt Tirols. III. Theil:Infusoria Ciliata und Tentaculifera HUXLEY. Zeitschrift des Ferdinandeums für Tirol, 3, 35, 191-209.

Dunning, C.G., Kern, J.J., Oxley, F., Parsons, F.A., \& Rousselet Ch. (1888) Objects found on the excursion to the gardens of the Royal Botanic Society of London. The Journal of the Quekett Microscopical Club, ser.2, 3, N 23, 292-293.

Ehrenberg, C.G. (1831) Über die Entwickelung und Lebensdauer der Infusionsthiere; nebst ferneren Beiträgen zu einer Vergleichung ihrer organischen Systeme. Abhandlungen der Akademie der Wissenschaften zu Berlin, year 1832, 1154, Pl. 1-4.

Fadeev, N.N. (1929) A list of aquatic animals from water bodies of the Donets Basin and adjacent localities from 1917 to 1927. Trudy Kharkivs'kogo tovarystva doslidnykiv pryrody, LII, 7-23. (In Russian).

Guhl, W. \& Guhl, H. (1993) Über Gehäusebau und Verschlußbildungen in der Familie Vaginicolidae (Ciliata, Peritricha). Zeitschrift für Angewandte Zoologie, 79, 3, 259-277.

Jankowski, A.W. (1989) Rossonophrys gen.n. (Peritricha), symbiont of Phyllocarids (Leptostraca). In: Sveshnikov V.A. (Ed.), Symbiosis in marine animals. Academy of Sciences of the USSR, Severtsov Institute of Evolution, Morphology and Ecology of Animals, Moscow, pp. 14-19. (In Russian with English summary).

Jankowski, A.W. (2007) Review of taxa phylum Ciliophora Doflein, 1901. In: Alimov A.F. (Ed.), Protista. Part 2, Handbook on Zoology. St.Petersburg: Nauka., pp. 415-993. (In Russian with English summary).

Kahl, A. (1933) Ciliata libera et ectocommensalia. In: Grimpe G. \& Wagler E. (Eds.), Die Tierwelt der Nord-und Ostsee, 23 (Teil II, c $c_{3}$ ), 29-146.

Kent, W.S. (1882) A Manual of the infusoria: including a description of all known flagellate, ciliate, and tentaculiferous protozoa British and foreign, and an account of the organization and affinities of the sponges. London: David 
Bogue, Vol. 3, 721-913, Pl. 41-51.

Lom, J. \& Puytorac, P. de (1994) Sous-classe des Peritrichia Stein, 1859. In: de Puytorac P. (Ed.), Traité de Zoologie. Anatomie, systématique, biologie. Vol. 2. Fasc. 2. Infusoires ciliés. Paris: Masson, pp.681-737.

Lynn, D.H. (2008) The Ciliated Protozoa. Characterization, classification, and guide to the literature. 3rd ed. Springer, $605 \mathrm{pp}$.

Matthes, D. (1958) Das peritriche Ciliat Cyclodonta bipartita (Stokes) nov.gen. Archiv für Protistenkunde, 102, 481500.

Naidu, K.V. (1965) Occurrence of two vaginicolid species (Peritricha: Ciliophora) from Chittoor, Andhra Pradesh. Current Science Bangalore (India), 34, 5, 151-152.

Paviour-Smith, K. (1956) The biotic community of a salt meadow in New Zealand. Transactions of the Royal Society of New Zealand, 83, 3, 525-554.

Peshkoff, M.A. (1934) Morphology and biology of Pixicola carteri S. Kent. Biologichesky Zhurnal, III, 2, 394-419. (In Russian with English summary).

Sommer, G. (1951) Die peritrichen Ciliaten des Großen Plőner Sees. Archiv für Hydrobiologie, 44, 3, 349-440.

Stokes, A.C. (1885) Notes on some apparently undescribed forms of freshwater infusoria No. 2. American Journal of Sciences, 29, 313-328.

Trueba, F.J. (1978) A taxonomic revision of the peritrich ciliate genus Pyxicola. Beaufortia, 27, $219-243$.

Wrześniowsky, A. (1866) Spis Wymoczków Spostrzeganych w Warszawie i jéj okolicach w Latach 1861 do 1865. Wyzak Szkoly Glównéj Warszawskiej, 5, 15-28. 